\title{
Tieteellisten lehtien tasoluokitus ja yliopistojen uusi rahoitusmalli
}

SUOMENKIELISTEN TIEDELEHTIEN tukala tulevaisuus kävi selväksi viimeistään vuonna 2009 tiedejulkaisujen Open Access -vaatimusten myötä: yliopistot alkoivat joko vaatia tai suositella, että tutkijat saattavat esimerkiksi Aikuiskasvatuksen kaltaisissa tieteellisissä lehdissä julkaisemansa artikkelit avoimeen ja maksuttomaan jakeluun netissä. Ilman kompensoivia tukia tämän toteutuminen tulee koettelemaan tiedelehtien kantokykyä: tilauskanta ja irtonumeromyynti romahtavat ja Kopiosto lakkaa maksamasta Elektra-korvauksia.

Nyt tiedelehdet ovat saaneet vastuksikseen uusia koettelemuksia, kun Tieteellisten seurain valtuuskunnan julkaisufoorumihanke ja opetus- ja kulttuuriministeriön asettama yliopistojen uutta rahoitusmallia kaavaillut työryhmä ovat saaneet työnsä valmiiksi.

\section{JULKAISUFOORUMIHANKE}

Vuonna 2009 yliopistojen rehtorien neuvoston työryhmä päätyi tieteellisten julkaisujen laatuarvioinnista tekemässään raportissa (http://rectors_council. helsinki.fi/raportit_ja_julkaisut/Julkaisujen_laadunarviointi.pdf), että vakiintuneet viittaustietokannat ja bibliometriset indikaattorit toimivat hyvin luonnon- ja lääketieteissä, osin teknisissä tieteissä, mutta heikommin yhteiskunta- ja humanistisissa tieteissä. Työryhmä esitti toteutettavaksi asiantuntijapaneelien suorittamaan arviointiin perustuvan kaikki tieteenalat kattavan lehtien, sarjojen ja kustantajien tasoluokituksen Tieteellisten seurain valtuuskunnassa (TSV). Opetus- ja kulttuuriministeriön rahoituksella perustettiin tätä varten julkaisufoorumihanke 2010. Paneelien jäsenet valittiin hankkeen ohjausryhmän kokouksessa 13.10.2010. Ohjausryhmä teki lisäksi täydentäviä henkilövalintoja kokouksessaan 1.2.2011.

Paneelien tehtävänä oli luokittaa tutkijoiden käyttämät julkaisukanavat (käytännössä tieteelliset aikakauskirjat, kirjankustantajat) neljään luokkaan, joista kolme nimettiin tieteellisiksi kolmelle laatutasolle. Esimerkiksi yliopistojen laitosten julkaisusarjat eivät yllä tieteellisiksi foorumeiksi vaan jäävät tasojen 1-3 ulkopuolelle eräänlaiseksi 0-tasoksi. Paneelit ovat toistaiseksi arvioineet yhteensä noin 22000 julkaisukanavaa.

Tasoluokittelun kriteerit tieteellisiksi arvioitujen julkaisufoorumien osalta ovat seuraavat:

\section{- Taso 1 =tieteelliset julkaisukanavat}

erikoistuneet tieteellisten tutkimustulosten julkaisuun; tieteenalan asiantuntijoista koostuva toimituskunta; julkaiseminen edellyttää laadunarviointia (vertaisarviointi); suunnattu ensisijaisesti alan asiantuntijayleisölle; kussakin paneelissa tasolle 1 luokitetaan vähintään 80 \% kaikista lehdistä/ sarjoista.

\section{- Taso 2 =johtavat tieteelliset julkaisukanavat} pääasiallisesti kansainvälisiä tieteellisiä lehtiä ja kus- 


\section{Julkaisufoorumihankkeen paneelit ja niiden tieteen alat sekä paneelin puheenjohtajat}

Paneeli 1: Matematiikka ja tilastotiede. Puheenjohtaja: Akatemiaprofessori Pekka Koskela, Jyväskylän yliopisto Paneeli 2: Tietojenkäsittely ja informaatiotieteet. Puheenjohtaja: Professori Esko Ukkonen, Helsingin yliopisto

Paneeli 3: Fysiikka, avaruustieteet ja tähtitiede. Puheenjohtaja: Professori Paula Eerola, Helsingin yliopisto

Paneeli 4: Kemia. Puheenjohtaja: Akatemiaprofessori Maarit Karppinen, Aalto-yliopisto

Paneeli 5: Geotieteet ja ympäristötieteet. Puheenjohtaja: Professori Markku Poutanen, Geodeettinen laitos Paneeli 6: Biotieteet I. Puheenjohtaja: Dosentti Hannu Pöysä, Riista- ja kalatalouden tutkimuslaitos

Paneeli 7: Biotieteet II. Puheenjohtaja: Professori Irma Thesleff, Helsingin yliopisto

Paneeli 8: Rakennus- ja yhdyskuntatekniikka, koneja valmistustekniikka. Puheenjohtaja: Professori Aki Mikkola, Lappeenrannan teknillinen yliopisto Paneeli 9: Sähkö- ja automaatiotekniikka, tieto- ja tietoliikennetekniikka. Puheenjohtaja: Akatemiaprofessori Visa Koivunen, Aalto-yliopisto Paneeli 10: Teknillinen kemia, materiaalitekniikka ja ympäristötekniikka. Puheenjohtaja: Professori Outi Krause, Aalto-yliopisto Paneeli 11: Lääketieteen tekniikka, bioteknologia ja peruslääketieteet. Puheenjohtaja: Professori Jukka Jurvelin, Itä-Suomen yliopisto
Paneeli 12: Kliiniset lääketieteet I. Puheenjohtaja: Professori Pirjo Nuutila, Turun yliopisto Paneeli 13: Kliiniset lääketieteet II ja hammaslääketieteet. Puheenjohtaja: Professori Jukka Meurman, Helsingin yliopisto

Paneeli 14: Terveystieteet ja muut lääketieteet. Puheenjohtaja: Tutkimuspäällikkö Kristiina Manderbacka, Terveyden ja hyvinvoinnin laitos

Paneeli 15: Maatalous- ja metsätieteet. Puheenjohtaja: Professori Annika Kangas, Helsingin yliopisto

Paneeli 16: Taloustieteet. Puheenjohtaja: Professori Juuso Välimäki, Aalto-yliopisto

Paneeli 17: Sosiaalitieteet, media- ja viestintätieteet sekä muut yhteiskuntatieteet. Puheenjohtaja: Professori Elianne Riska, Helsingin yliopisto

Paneeli 18: Psykologia ja kasvatustieteet. Puheenjohtaja: Professori Jarkko Hautamäki, Helsingin yliopisto

Paneeli 19: Politiikan tutkimus, hallintotiede ja oikeustiede. Puheenjohtaja: Professori Carsten Anckar, Åbo Akademi

Paneeli 20: Filosofia ja teologia. Puheenjohtaja: Professori Sami Pihlström, Helsingin yliopisto

Paneeli 21: Kielitieteet. Puheenjohtaja:

Akatemiaprofessori Terttu Nevalainen, Helsingin yliopisto Paneeli 22: Kirjallisuus, taiteen tutkimus ja arkkitehtuuri. Puheenjohtaja: Professori Pekka Korvenmaa, Aalto-yliopisto

Paneeli 23: Historia, arkeologia ja kulttuurien tutkimus. Puheenjohtaja: Professori Pirjo Markkola, Jyväskylän yliopisto tantajia, joiden toimitus-, kirjoittaja- ja lukijakunta edustaa eri kansallisuuksia; kanavia joissa tutkijat eri maista julkaisevat parhainta tutkimustaan, kussakin paneelissa tasolle 2 luokittuu enintään $20 \%$ kaikista lehdistä/sarjoista.

\section{- Taso 3=korkeimman tason johtavat tieteelli- set lehdet ja sarjat}

käytännössä kaikki julkaistu tutkimus on korkeinta tasoa omalla tieteen- tai tutkimusalallaan; kattavat tieteen- tai tutkimusalaa laajemmin; toimituskunnissa tieteen- tai tutkimusalan johtavat tutkijat; julkaisemista näissä lehdissä ja sarjoissa arvostetaan erittäin korkealle, kussakin paneelissa tasolle 3 luokittuu enintään $25 \%$ tason 2 lehdistä, eli $5 \%$ paneelin kaikista lehdistä.

Tammikuun 30. päivän tietojen mukaan julkaisufoorumihanke on arvottanut lähes kaikki suomenkieliset tieteelliset aikakausjulkaisut tasolle 1. Yhteiskunta- ja humanististen tieteiden alan lehdistä luokkaan kuuluvat mm.

Aikuiskasvatus,

Erityiskasvatus,

Hallinnon tutkimus,

Informaatiotutkimus,

Janus,

Kansantaloudellinen aikakauskirja,

Kasvatus,

Kasvatus \& Aika,

Kulttuurintutkimus,

Naistutkimus,

Niin \& Näin,

Nuorisotutkimus,

Peda-forum,

Politiikka,

Psykologia,

Sosiaalilääketieteellinen aikakauslehti,

Sosiologia,

Tiede \& Edistys,

Tiedepolitiikka, 
Työelämän tutkimus,

Työväentutkimus,

Yhdyskuntasuunnittelu,

Yhteiskuntapolitiikka.

Tasolle 2 kuuluvat Suomen Historiallisen Seuran ja Historian Ystäväin Liiton julkaisema Historiallinen aikakauskirja ja vuonna 1897 perustettu, suomen kielen ja sen opetuksen tutkimusta esittelevä Virittäjä.

Tieteellisten aikakausjulkaisujen lisäksi paneelit arvioivat (kirjan)kustantajat. Tieteellisiksi arvioiduista kirjankustantajista vähintään 80 prosenttia luokittuu tasolle 1 ja 20 prosenttia tasolle 2 . Suomenkielisen tiedejulkaisemisen kannalta on myönteistä, että paneelit luokittivat Gaudeamuksen, Vastapainon, Suomalaisen tiedeakatemian ja Suomalaisen Kirjallisuuden Seuran tasolle 2. Mutta esimerkiksi Suomen Kasvatustieteellinen Seura (julkaisusarja Kasvatusalan tutkimuksia) ja Atena Kustannus on sijoitettu tasolle 1. Sen sijaan sellaiset kustantajat, kuten Tammi ja vaikkapa runsaasti kasvatusalan tutkimusta julkaiseva PS-Kustannus eivät (ainakaan tässä vaiheessa) luokitu 'tiedekustantajiksi' eli eivät päässeet edes tasolle 1 .

Julkaisufoorumihankkeen ohjausryhmän puheenjohtajan Ilkka Niiniluodon mukaan (Julkaisufoorumiseminaari 6.2.2012) hankkeen yhtenä keskeisenä tavoitteena on välittää tutkijoille tietoa julkaisukanavien laadusta ja kannustaa suomalaisia tutkijoita kansainväliseen julkaisemiseen. Tällä julkaisufoorumien laadukkuuden tunnetuksi tekemisellä halutaan nostaa suomalaistutkijoiden ambitiotasoa ja saada tutkijat päämäärätietoisemmin tarjoamaan tutkimuksiaan maailman parhaisiin julkaisusarjoihin. Luokitus ei siis ole tarkoitettu vain kuvaukseksi maailman tieteellisen julkaisujen laatutasosta ja keskinäisestä paremmuusjärjestyksestä. Sen tarkoitus on toimia ohjausvälineenä. Tasoluokituksen on määrä ohjata yliopistojen henkilöstö (a) julkaisemaan nykyistä enemmän kansainvälisillä (käytännössä englanninkielisillä) foorumeilla ja (b) mahdollisimman suuren osan tutkimuksistaan kansainvälisten julkaisukanavien tasolla 2 ja 3.

\section{YLIOPISTOJEN UUSI RAHOITUSMALLI}

Kun julkaisufoorumihankkeen paneelit aloittivat työnsä, niiden jäsenillä ei ollut kovinkaan tarkkaa tietoa siitä, miten tasoluokitusta tultaisiin käyttämään yliopistojen rahanjaon välineenä.

Opetus- ja kulttuuriministeriö asetti 15.3.2011 työryhmän laatimaan ehdotuksen yliopistojen voimassa olevan rahoitusmallin tarkastamiseksi ja uudistamiseksi. Työryhmän puheenjohtajana toimi johtaja Anita Lehikoinen opetus- ja kulttuuriministeriöstä. Ehdotuksen laadinnassa tuli ottaa huomioon yliopistolaitoksen ja yksittäisten yliopistojen toiminnan laadun, vaikuttavuuden ja tuottavuuden vahvistaminen sekä laatia ehdotukset tarvittavista säädösmuutoksista ja muista toimenpiteistä.

Opetus- ja kulttuuriministeriön työryhmän marraskuussa 2011 julkistaman, Laadukas, kansainvälinen, profiloitunut ja vaikuttava yliopisto -raportiksi kirjatun ehdotuksen mukaan yliopistojen perusrahoitus jaetaan entistä selvemmin tulosten perusteella. Tuloksia ovat esimerkiksi suoritetut tutkinnot ja julkaistut tutkimukset. Rahoitusmallin perusteet jakautuvat mallissa kolmeen osa-alueeseen: (1) koulutukseen, (2) tutkimukseen ja (3) 'muihin koulutus ja tiedepoliittisiin tavoitteisiin'. Koulutuksen tuloksia kuvaavien tekijöiden perusteella perusrahoituksesta jaetaan 41 prosenttia ja tutkimustoimintaa kuvaavien tekijöiden perusteella 34 prosenttia. Loput 25 prosenttia perusrahoituksesta jaetaan 'muiden koulutus- ja tiedepolitiikan tavoitteiden' mukaan.

Rahoitusmalliehdotuksen tutkimusosion rahoituskriteereillä on tarkoitus kannustaa yliopistoja tutkimustoiminnan perusedellytysten, kuten tutkimushenkilöstön, tutkijankoulutuksen ja tutkijanuran kehittämiseen, tutkimustoiminnan edellyttämän infrastruktuurin vahvistamiseen ja kansainvälistymiseen.

Tiedekustantamisen ja julkaisutoiminnan kannalta kiinnostus kohdistuu tutkimukseen ja sen 34 prosentin osuuden sisäiseen jakautumiseen. Työryhmä ehdottaa, että tutkimusosiossa mallin perusteella jaettava rahoitus määritetään seuraavien toiminnan vaikuttavuutta, laatua ja kansainvälisyyttä kuvaavien tekijöiden perusteella (\% mallilla jaettavasta perusrahoituksesta):

Suoritetut tohtorintutkinnot $9 \%$

Julkaisut $13 \%$, josta kansainväliset

refereejulkaisut $10 \%$ ja 
muut tieteelliset julkaisut $3 \%$

Kilpailtu tutkimusrahoitus $9 \%$, josta

kansainvälinen kilpailtu tutkimusrahoitus $3 \%$ ja

muu kilpailtu tutkimusrahoitus $6 \%$

Ulkomaalaisten suorittamat tohtorintutkinnot $1 \%$

Ulkomaalainen opetus- ja tutkimushenkilöstö $2 \%$

Julkaisut ovat eittämättä yliopistojen tutkimustoiminnan keskeisin tuotos. Tähän saakka julkaisutoiminnan perusteella on jaettu alle kaksi prosenttia perusrahoituksesta, esitetyn mallin mukaan se nousee 13 prosenttiin eli moninkertaiseksi. Rahoitusperusteiden uudistamisella ministeriö tavoittelee yliopistojen 'kansainvälistymistä' ja 'laadukkuutta'. Rahoitusmalli on laadittu tukemaan sitä.

Tässä kohtaa rahoitusmalliin yhdistetään julkaisufoorumihankkeen paneeleissa tehty julkaisujen ja kustantajien tasoluokitus. Vuodesta 2013 alkaen (a) kymmenen prosenttia perusrahoituksesta määräytyisi kansainvälisten refereejulkaisujen määrän perusteella ja (b) kolme prosenttia muiden tieteellisten julkaisujen määrän perusteella. Jälkimmäiseen (muut tieteelliset julkaisut) kolmeen prosenttiin sisältyvät myös suomenkieliset julkaisut. Yhden kansainvälisen julkaisun rahallinen arvo yliopistolle on siis monikertainen suomenkieliseen julkaisuun verrattuna

Ministeriön työryhmän ehdotuksen mukaan perusteet hieman muuttuisivat uudelleen vuodesta 2015 alkaen. Silloin on määrä ottaa julkaisujen arvottamisperusteina käyttöön julkaisufoorumihankkeessa laadittu tieteellisten julkaisujen luokittelu. A-ryhmän eli kansainvälisten refereejulkaisujen sijaan otetaan käyttöön julkaisufoorumin tasojen 2 ja 3 julkaisujen kategoria sekä B-ryhmän eli 'muiden tieteellisten julkaisujen' sijaan julkaisufoorumin tason 1 julkaisujen kategoria.

Vuonna 2011 valtion yliopistoille osoittama yliopistolain mukainen valtion rahoitus oli yli 1,8 miljardia euroa, joka kattaa noin kaksi kolmasosaa yliopistojen kokonaisrahoituksesta. Esitetyn uuden rahoitusmallin mukaan tulevina vuosina yliopistojen perusrahoituksesta (10\%) 180 miljoonaa jaetaan kansainvälisen julkaisutoiminnan perusteella (vuodesta 2015 alkaen siis 2- ja 3- tasolle luokittuvien julkaisujen perusteella). Suomenkielisen julkaisutoiminnan perusteella jaetaan 54 miljoonaa.

\section{TASOLUOKITUKSEN JA RAHOITUKSEN YHTEEN KYTKEMISEN SEURAUKSET}

Ei-suomenkieliset julkaisut näyttävät olleen OKM:n rahoitusmallityöryhmälle lähtökohtaisesti korkeampilaatuisia kuin suomenkieliset. Epäilemättä parhaat kansainväliset tieteelliset aikakauslehdet ovat korkealaatuisempia kuin suomenkieliset keskimäärin. Sitä ei käy kiistäminen. Artikkelin saaminen parhaisiin englanninkielisiin tiedelehtiin on kovemmin kilpailtua, ja niiden arviointiprosessin läpäisevät vain suuresta joukosta parhaina valitut artikkelit. Mutta nyt tehty tiedelehtien nimeäminen eritasoisiksi ja tähän eriarvoisuuteen perustuva rahanjako saattavat johtaa suomenkielisen tiedejulkaisemisen ja suomen kielellä käydyn julkisen tieteellisen keskustelun kannalta epätoivottaviin seurauksiin.

Se, että yliopistoja ohjataan kansainvälistymään tällä tavoin, tarkoittaa käytännössä yliopistojen henkilöstön paimentamista laatimaan mahdollisimman suuri osa julkaisuistaan englannin kielellä suomen kielen sijaan. Runsaasti englannin kielellä julkaisevat ovat yliopistotyönantajalleen arvokkaampia, koska heidän työnsä tuottaa enemmän rahoitusta. Toki henkilöstö voi edelleenkin julkaista suomenkielisiä artikkeleita ja kirjoja, mutta suomenkieliseen kirjoittamiseen käytetty aika ja työpanos ovat pois arvokkaammasta työstä eli vieraskielisestä (kansainvälisestä) kirjoittamisesta. Useimmalle äidinkielenään suomea puhuvalle kirjoittaminen vieraalla kielellä vie enemmän aikaa kuin suomenkielisen tekstin laatiminen. Suomenkielinen kirjoittaminen ja julkaisemi- 
nen eivät siis ole vain tutkijan halusta kiinni: sille jää yksinkertaisesti entistä vähemmän aikaa.

Edes kritisoimatta millään tavoin tiedejulkaisujen arvioinnin ja luokituksen pätevyyttä on aiheellista huolestua siitä, että luokittelu saattaa toimia itseään toteuttavana ennustuksena. Kun (lähes kaikki suomenkieliset) julkaisut on nyt nimetty alimman tason julkaisuiksi, parhaiden tutkijoiden ei kannata tarjota artikkeleita niihin senkään vuoksi. 1-tason julkaisuina suomenkieliset tieteelliset aikakauslehdet voivat joutua huonoon kehään: jos artikkelien tarjonta vähenee ja kirjoittajakunta heikkenee, lehden nouseminen 2-tason julkaisuksi on mahdoton tehtävä.

Toki on edelleenkin niin, että tutkijoiden kannattaa mieluummin julkaista suomen kielellä kuin olla julkaisematta lainkaan. Mutta tutkijan lähtökohta työssään on tästä lähtien ilman muuta se, että hän kirjoittaa ensi sijassa englannin kielellä. Vaarana vain on se, että tulevaisuudessa suomenkielisten tiedelehtien palstoille saadaan aiempaa vähemmän suomalaisten 'huippututkijoiden' artikkeleita, vaikka ehkä juuri ne olisivat - ei vain tieteellisen keskustelun kehittymisen - vaan esimerkiksi yliopisto-opiskelijoiden ja yhteiskunnallisen keskustelun kannalta arvokkaimpia.

Osassa luonnontieteitä tieteelliset artikkelit ovat sellaisia, että niiden potentiaalinen suomalainen lukijakunta ei paljoakaan pienene siitä, että tutkimukset julkaistaan vain englannin kielellä. Niin on tehty tähänkin asti. Luonnontieteiden tulosten julkaiseminen suomalaiselle yleisölle edellyttää taitavaa popularisointia, joka taas on oma julkaisumuotonsa. Mutta esimerkiksi kasvatustieteissä ja muissa yhteiskunta- ja humanistisissa tieteissä suomenkielisen tieteellisen julkaisemisen väheneminen pienentää potentiaalisten 'tiedelukijoiden' määrää Suomessa. Esimerkiksi Aikuiskasvatusta, Kasvatusta, Nuorisotutkimusta, Politiikkaa, Sosiologiaa ja Yhteiskuntapolitiikkaa lukevat paljon muutkin kuin ammattitutkijat. Usein niissä esitetään tutkimuksia omasta yhteiskunnastamme, ja siksi ne kiinnostavat (usein vain) meitä suomalaisia.

Ensisijaisesti ulkomaisiin julkaisuihin tähtäävä tutkija joutuu myös tarkoin miettimään tutkimuskohdettaan: kannattaako enää tutkia suomalaista todellisuutta, jos riskinä on vaikeus saada tuloksia julkaistuksi ulkomaisissa tiedejulkaisuissa? Suomalaisissa tiedelehdissä ei artikkelia pidetä epärelevantteina sillä perusteella, että siinä esitetyt tulokset koskevat vain viisimiljoonaisen väestön oloja jossain pohjoisessa periferiassa.

\section{TIEDELEHTIEN NÄKYMÄTÖN TYÖ}

Suomenkielisten tieteellisten aikakauslehtien tilanne on viime vuosikymmenten mittaan muuttunut olennaisella tavalla yliopistolaitokseen ja yliopistoissa tutkimustyötä harjoittaviin kohdistuvien koventuneiden paineiden vuoksi. Tiedelehtien ahdinkoa kärjistää yliopistolaitoksen muutos kokonaisuudessaan, ei vain uusi rahoitusmalli. Kun yliopistojen työtahti on tiukentunut ja henkilöstön tekemisiä tarkkaillaan ja arvioidaan entistä tarkemmin, varsinaisten työtehtävien ulkopuoliseen tieteelliseen toimintaan, kuten tieteellisiin seuroihin ja niiden aikakauslehtiin jää entistä vähemmän aikaa ja mahdollisuuksia. Eikä aikaa vievään 'tieteelliseen talkootyöhön’ osallistuminen ole enää järkevääkään, koska sekin aika on tarkoituksenmukaista käyttää niihin tehtäviin, joita työnantaja mittaa ja arvostaa ja joista ministeriö palkitsee rahoituksella.

Tieteellisten lehtien on entistä vaikeampaa saada yliopistotutkijoita toimituskuntaan ja refereiksi arvioimaan artikkelikäsikirjoituksia. Nykyisin refereiden rekrytointi ei käy ihan helposti, koska yliopistotutkijoille toimiminen refereinä on vapaaehtoistyötä. Toiminta refereenä jää näkymättömäksi työksi. Se näkyy korkeintaan siten, että usein lausunnonantajana toimiva ehtii itse julkaista vähemmän. Usein kiireisten refereiden arviot viivästyvät, mikä on omiaan vaikeuttamaan lehtien toimitustyötä.

Toimituskunnan työ ei kutistu vain käsikirjoitusten vastaanottamiseen ja lähettämiseen refereille. Toimituskunta lukee joukolla suuren määrän tarjottuja tekstejä tehden ensimmäisen arvion käsikirjoituksen kelvollisuudesta ja sopivuudesta lehteen. Usein kiinnostava käsikirjoitus ei ole sellaisenaan kelvollinen lähetettäväksi lausunnonantajalle, vaan toimituskunta ehdottaa kirjoittajaa tekemään siihen korjauksia, joita tietää lausunnonantajien joka tapauksessa esittävän tehtäväksi. Joskus toimituskunnan ohjeet merkitsevät suurtakin remonttia käsikirjoitukseen. 
Tutkijoilla itsellään luonnollisesti on intressi korkeatasoisiin julkaisufoorumeihin, mutta olisi toivottavaa, että valtiovalta (opetusministeriö) ei ainakaan vaikeuttaisi suomalaisen tiedelehdistön toimintaedellytyksiä. Asiantunteva ja aktiivinen kansalaiskeskustelukin edellyttää perustakseen maan parhaasta tutkimuksesta ammentavaa tiedelehdistöä. Tiedämme, etteivät tutkijat periaatteessa hyljeksi julkaisemista suomen kielellä, mutta miten heidän työnantajansa suhtautuvat tällaisiin 'heikosti (rahaa) tuottaviin' yksilöihin, on tulevaisuuden avainkysymys suomalaisten tiedelehtien kannalta.

Jotta yliopistotutkijoilla olisi mahdollisuuksia osallistua suomenkielisen tiedelehdistön työhön ja julkaisemiseen suomen kielellä, kaikkinainen toiminta tieteellisissä seuroissa, tieteellisten konferenssien järjestämisessä, tieteellisten aikakauslehtien toimituskunnissa ja refereetoiminnassa on saatava näkyväksi ja tehtävä tunnustetuksi osaksi yliopistotutkijan työtä.

\section{VALOA TUNNELIN PÄÄSSÄ?}

Suomalaiset tiedeseurat ovat reagoineet voimakkaasti julkaisufoorumihankkeen tasoluokituksen ja ministeriön rahoituksen allokoinnin yhdistämiseen. Tiedeseurojen esiintulolla näyttää olevan myös vaikutusta. Tässäkin lehdessä nyt julkaistavan yli 60 suomalaisen tiedeseuran allekirjoittaman kannanoton seurauksena Tieteellisten seurain valtuuskunnan julkaisufoorumihankkeen ohjausryhmä teki 3. helmikuuta 2012 päätöksen, jonka mukaan

"tieteellisen julkaisemisen kieltä koskevat kysymykset ovat tärkeitä ennen kaikkea yhteiskuntatieteellisen ja humanistisen tutkimuksen kannalta. Keskustelun perusteella ohjausryhmä päätti, että paneelit 14 ja 16-23 voivat halutessaan luokitella tasolle 2 suomen- tai ruotsinkielisiä johtavia tieteellisiä lehtiä, jotka kattavat tieteenalansa suomalaisen yhteiskunnan, kulttuurin ja historian erityispiirteitä käsittelevää tutkimusta mahdollisimman laajasti. ESF:n ERIH-luokituksen tieteenalat kattavat paneelit voivat halutessaan luokitella tasolle 2 muilla kuin yksinomaan englanninkielellä julkaisevia, ERIH-arvioinnissa tasolle A-luokiteltuja lehtiä ja sarjoja. Julkaisufoorumin sihteeristö ryhtyy toteuttamaan päätöstä em. paneelien kanssa kevään 2012 aikana."

Päätöstä on syytä pitää suomenkielisen tiedejulkaisemisen kannalta erittäin merkittävänä.

Toinen myönteinen uutinen liittyy ministeriön työryhmän ehdottamaan yliopistojen rahoitusmalliin. Julkaisufoorumihankkeen seminaarissa 6.2. 2012 johtaja Anita Lehikoinen ministeriöstä totesi ehdotetun yliopistojen rahoitusmallin jakosuhteiden olevan julkaisutoiminnan osalta tarkistettavissa. Kansainvälisten refereejulkaisujen painoarvo voi olla ehdotetun 10 prosentin sijaan pienempikin, esimerkiksi yhdeksän prosenttia ja vastaavasti 'muiden tieteellisten julkaisujen painoarvo voidaan asettaa ehdotettua kolmea prosenttia suuremmaksikin, esimerkiksi neljäksi prosentiksi. Jakosuhteen lieventäminen on ilman muuta eduksi suomenkielisen tiedelehdistön säilymisen ja kehittymisen kannalta. Mutta jakosuhde 9 prosenttia vs. 4 prosenttia on sekin kovin jyrkkä - 8 prosenttia vs. 5 prosenttia saattaisi olla siedettävä eikä suistaisi lehtiä välittömästi entistä vaikeampaan ahdinkoon.

Jos on merkityksellistä puhua sellaisista asioista kuin 'kansakunnan sivistystaso' tai väestön sivistyksellinen ja kulttuurinen valveutuneisuus, pitäisi ensi sijassa valtiovallan olla kiinnostunut luomaan parhaat mahdolliset edellytykset tiedelehdille. Sivistystason nostaminen ei ole enää vain väestön muodollisen koulutustason nostamista. Mitä suurempi osa väestöstä on korkeasti koulutettua, sitä suurempi on tiedelehtien potentiaalinen lukijakunta, ja sitä perustellumpaa on koettaa pitää suomenkielistä tiedelehdistöä yllä. Ja on suorastaan järjetöntä luokittaa tieteellinen aikakauslehti jollekin tasolle vain sen kielen vuoksi. Suomalainenkin tiedelehti voi olla korkeatasoinen ja tieteellisesti laadukas.

Kirjoittaja on Aikuiskasvatuksen päätoimittaja. 